\title{
FOULING IN THE PEARL OYSTER BEDS OF THE QATARI WATERS, ARABIAN GULF
}

\author{
Jassim A. Al-Khayat and Ibrahim A. Al-Maslamani \\ Marine Scjences Department, Faculty of Science, \\ University of Qatar, Doha P. O. Box 2713, Qatar
}

Keywords : Macrofouling, pearl oyster, community structure, Arabian Gulf, Qatar.

\section{ABSTRACT}

Fouling organisms at twelve different pearl oyster beds in the Qatari $F$ waters of the Arabian Gulf have been examined and their degree of abundance was assessed. The majority of fouling organisms were algae, sponges, bryozoans, polychaetes, crustaceans, gastropods, bivalves, amphineurans, stelleroida, actinozoans, hydrozoans and ascidians. The list of fouling species identified included a total of 111 species. The highest number recorded of fouling species was at Akraiyash site with the highest diversity index, while the Icast number was reported in Um Al-Cheteb with the lowest diversity index.

\section{INTRODUCTION}

Fouling communities consist of mixtures of algae, barnacles, bivalves, bryozoans, hydroids, tube worms, tunicates, sponges and other suspension feeding invertebrates that grow on all submerged surfaces. Ship bottoms, outfall pipes, hard surfaces of sea animals and any object that had been discarded in the sea are soon colonized by marine fouling organisms. These submerged surfaces are favourable both for settlement and growth of larvae, of algae and of sessile invertebrates. Valiela (1995) reported that fouling of hard surfaces has great economic interest and has been the subject of numerous stidies. The species that make up these communities are those that would settle on any hard surface subtidally and fouling communities therefore form over a sizeable portion of the coastal bottom.

In the central part of the Arabian Gulf, the pearl oysters Pinctada radiata and Pincrada margaritifera occur abundantly. Their communities contribute hard surfaces of natural or artificial structures 
for the colonizing fouling organisms. Unforunately. there is no base line data dealing with fouling communities. their composition. distribution. seasonal abundance. population size and their effect on the Gulf navigation. marine constructions or marine animals. The present study is the first so far. aiming to record and identify fouling organisms, with special reference to those that settle on the shells of the pearl oyster Pinclada radiala inhabiting its beds in the Qatari waters.

\section{MATERIAL AND METHODS}

Twelve stations of pearl oyster beds in the eastern coast of the Qatari waters were selected for this survey. The sampling surveys of the different stations of the oyster beds were carried out using SCUBA diving. Each station was visited once during the period from September 1999 to December 1999 by the research vessel "Mukhtaber Al-Bihar" of the University of Qatar (Fig.1). Macrofouling specimens and hand collected from the oyster beds and preserved in 10\% buffered formalin in seawater solution. In the laboratory, the oyster shell valves were carefully cleaned of all macro-fouling organisms. All preserved macro-fouling organisms were sorted out and identified as far as possible.

\section{RESULTS}

Biofouling communities prevailing on the shells of pearl oyster in the Qatari waters consist in their majority of crustaceans ( 32 spp), molluscs (27 spp), polychaetes (24 spp), sponges (11 spp), stelleroides ( $6 \mathrm{spp}$ ), actinozoans ( $3 \mathrm{spp}$ ), hydrozons ( $2 \mathrm{spp}$ ), ascidians (2 spp), bryozoans (1 spp) and 3 algae species (Fig. 2). Table 1 shows the relative abundance of settlements on the shells of the pearl oysters at the different stations. A total of 988 fouling organisms were collected and identified. They were classified to the following groups:

\section{Crustacea}

Crustacea were the most abundant taxa and the representatives of this class in the pearl oyster beds belonged to the subclass Cirripedia and to the orders Cumacea, Isopoda. Amphipoda and Decapoda (Caridea. Anomura and Brachyura). Although the most common fouling barnacle was Balanus amphitrite, it was only 
represented in 4 stations. Amphipoda was represented by 10 species. One unidentified species of amphipods was abundant at station QS2 and frequent in stations QS1. QS3 and QS9. Cymodisa filosa. Orchesta platensis and Grandidierella cxilis were present at 5 stations. each with a different degree of abundance (Table 1). Other amphipods were also encountered in varying quantities in the samples. Among them were Cymodusa sp. Elasmopus pectinicrus, Perioculodes longimamus, Plaryischmopus herdamani. Uroylioe grimaldi and Urothoes sp.

Two lsopod species were found: Cymodoce sp and Sphaeroma annadalei and few individuals of Alpheidea, Penaeidea shrimps and Xanthidae crabs were observed in some samples (Table 1).

\section{Mollusca}

The second highest abundant taxa were the molluscs ( $27 \mathrm{spp}$.), specially bivalves and gastropods with the former represented by 18 species and the latter by 9 species. The bivalves Chama aspera, Brachidontes emarginatus and Brachidontes sp were dominant in 6 stations (Table 1). Pinciada radiata spats were the most widespread and were settled on the oldest oyster shells, as well as on all hard surfaces. Settlements of Pinctada radiata spats were observed in most stations of the peari oyster beds. Few individuals of gastropods were represented in most samples, except for Doriopsilla miniata which was represented by 8 individuals in station QS1 and 6 specimens in station QS4.

In the present investigation, only one species of Amphineura Ischnochiton sp was found and encountered in 4 stations, namely QS2, QS3, QS7 and QS8.

\section{Polychaeta}

Both sedentary and errantic polychaetes predominated among fouling growths. Most common fouling species in the pearl oyster beds were Neries sp and Eunice sp which were present in 8 stations. Eunice antennata and other polychaete spp. were only found in 4 stations. Hydroides sp was present in 5 stations and Janua kayi was present in 6 stations, while the other collected fouling organisms of the polychaetes were observed at 1-3 stations. Almost all pearl oyster beds investigated were infested by fouling worms varying from one worm to over 35 worms per $\mathrm{m}^{2}$. 


\section{Demospongiae}

The sponges were markedly spread along most stations of the pearl oyster beds. The colonies sampled constituted of 11 species (Table 1). The most dominant species encountered was Haliclona sp which appeared in 7 stations.

Stelleroida

Brittle stars are mostly scavengers and settle on oyster shells often for feeding on debris and small animals. The most common species were Macrophiothrix sp, Op, hiothela danae, Ophiothela sp,O.savignyi, Ophiothrix sp and Orphionereis dubia. Ophiothrix savignyi was the most dominant and flourished in 7 stations.

\section{Actinozoa}

The actiozoan animals were represented by 3 species, namely: Calliactus polypus, Diadumene sp and Panacyathus cavatus with the latter being most dominant and highly abundant at stations QS1, QS5 and QS10.

\section{Hydrozoa}

The main hydrozoan settlers on the oyster shells were Obelia dichotoma and Obelia sp. The first species appeared only at station QS11, while the second species was confined to stations QS10 and QS11.

\section{Ascidiacea}

Foulers of these urochordate organisms were found on the shells of pearl oysters in 4 stations (Table 1). Didemnum sp and Phallusia nigra were the chief settling ascidians and their largest population was at Umm-Al-Jash (QS11).

\section{Bryozoa}

Only one organism namely Schizoporella errata was recorded it is thought to represent an important fouling organism, where its colony formed broad laminar encrustation. It was only found in one station, (Hallah Dalmma, QS5).

\section{Algae}

Several algae species belonging to different groups were common in the Qatari waters. However, the most prevailing species on the shells of pearl oysters were: Acannthophora sp, Hypena sp and Liagora distenta. These Rhodophyta (red algae) species were the most common and appeared throughout most oyster beds.

\section{Species Diversity}

The Shannon and evenness indices showed relatively high values at station QS2 $(\mathrm{D}=2.890, E=0.841)$ and station QS11 $(D=2.824, E=0.857)$, while relatively lower values were reported at 
station QS6 $(D=2.084, E=0.605)$ and station $Q S 5(D=2.262, E=0.835)$ (Table. 2). The taxa abundance data showed that fouling at station QS2 was composed of three major groups vis; Crustacea. Polychaeta and Mollusca. The relative numerical abundance of crustacean taxa was Amphipoda sp (undetermined) (13.9\% by no.) and the polychaete Eunice sp (17.1\% by no.)

The highest number of fouling taxa ( $31 \mathrm{spp}$.) was found at station QS2 followed by 28 species at QS10, while lower numbers were found at stations QS5, QS6 and QS12. Similarly. the highest number of crustacean species was observed at station QS2 (12 spp.) as compared to other stations (2-9 spp.). The highest number of polychaete species was found at station QS2 (10 spp.). as compared to other stations (2-7 spp.). Number of molluscan taxa was only high at station QS10 (10 spp.), as compared to that found at other stations (2-7 spp.). The number of species in other taxa were relativcly low in all stations (Fig. 2).

The details of the numbers and percentage of the different fouling groups and their representation at the investagated sites are summerised in Table 3 which showed that:

\section{Station QS1 (Um-Khort)}

Twenty six fouling species (23.4\%) were recorded from this station during the period of the study. The crustaceans were the most abundant, having 9 species (34.6\%). Polychaetes 7 specics $(26.9 \%)$ and molluses 5 species (19.2\%). The other classes were lowest and only represented by 1 species (3.9\%) for each of them (Table 3 ).

\section{Station QS2 (Akraiyash)}

This station was harboured by highest number of fouling species (30 spp.; 27.9\%). The Crustacea and Polychaeta were the commonest, having 10 species for each and represening $37.5 \%$ of the total species recorded from this station. Mollusca and Stelleroida were represented by 4 species (13.3\%) and 3 species (10.0\%) respectively, while Demospongia, Actinozoa and Ascidiacea were represented by 1 species for each $(3.3 \%)$.

\section{Station QS3 (Um-Alotheam)}

Twenty three fouling species $(20.7 \%)$ were collected from this station during the period of study. The Polychaeta was the richest, 
having 6 species $(26.1 \%)$. The Crustacea and Mollusca were represented by 5 species $(21.7 \%)$ and 4 species $(17.4 \%)$ respectively. Station QS4 (Botheal)

Seventeen fouling species $(15.3 \%)$ were recorded from this station. The Polychaeta and Mollusca were represented by 5 species (29\%) for each of them and Crustacea was represented by $4(23.5 \%)$. The rest of fouling species were represented by only a single species $(5.9 \%)$.

\section{Station QS5 (Hallah Dalmma)}

Sixteen fouling species $(13.5 \%)$ were found in this station. The Mollusca was the richest, having higher number of species ( 6 spp). The occurrence of other species was: 3 fouling species of Polycheata (18.8\%) while Stelleroida, Demospongia were represented by one species for each. The Crustacea and Actinozoa were represented by only 2 species for each.

\section{Station QS6 (Um-Al-Cheteb)}

Ten fouling species $(9.0 \%)$ were sampled from this locality during the period of the study. The Crustacea was the richest, having 5 species (50\%), while Polycheata and Mollusca were represented by 3 and 2 species respectively.

\section{Station QS7 (Alead-Al-Gharbi)}

Twenty one fouling species $(18.9 \%)$ were collected from this station. The Crustacea was the richest, having 8 species $(30.1 \%)$, followed by Polycheata with 6 species, while the other groups were represented only by 1-2 species.

\section{Station QS8 (Tunob)}

Twenty four fouling species $(21.6 \%)$ were obtained in this station. The Crustacea, Polychaeta and Mollusca were the richest, having 7,6 and 7 species respectively. The Stelleroida and algae were represented by 3 and 1 respectively.

Station QS9 (Al-Haded)

Eighteen fouling species (16.2\%) were collected from this station. The Crustacea was the richest, having 7 species (38.9\%). The Polycheata and Mollusca were represented by 4 species for each of them, while the Stelleroida was represented by 1 species $(5.6 \%)$ and Demospongia was represented by 2 species (11.1\%). 


\section{Station QS10 (Bil-Hanmber)}

Twenrty eight fouling species $(25.2 \%)$ were recorded from this station. The Mollusca was the richest, having 12 species (42.9\%). The Crustacea, Polycheata and Demospongia were represented by 5 . 4 and 3 species respectively, while the other taxa were only represented by 1 species for each.

\section{Station QS11 (Um-Al-Shef-Laffan)}

Twenty seven fouling species (24.3\%) were found in this station. The Polychaeta, Mollusca, Demospongia and Crustacea were represented by $6,7,5$ and 4 species respectively. respectively. The other taxa were lowest, having only a single species for each.

\section{Station QS12 (Um-Al-Jash)}

Fifteen fouling species (13.5\%) were sampled from this station. The Polycheata was represented by 2 species, while the the other taxa of fouling species wcre only represented by one species $(6.7 \%)$ for each.

\section{DISCUSSION}

Most of benthic marine organisms are prone to fouling. Some of them have no obvious physical defenses against foulers, but they are chemically defended against fouling settlement (Henrikson, et al.,1998), while the other fouling organisms induce various antifouling and cleaning behavior. These can include the use of the foot as in Mytilus sp (Raffaelli \& Hawkins, 1996) or by wiping the shell clean and perhaps laying down a protective mucus coating as in Calliostoma zizyphinium (Jones, 1984). Animals with limbs, such as amphipods and decapods, can groom themselves, and epizooites will also be lost when they moult. Echinoderms use pincer-like pedicellaria to remove settling propagules (Raffaelli \& Hawkins, 1996). Conversely, animals such as spider crabs actively encourage a growth of living seaweed. which provide a camouflage. Sea urchins, such as Paracentrotus, trap loose materials such as seaweed and cells to cover their upper surfaces. This may help increase crypsis and, as in the case of algal coverings, to provide food (Raffaelli \& Hawkins, 1996). 
In the central part of the Arabian Gulf, the peari oysters Pinictada margaritifera and Pinctada radiala occur abundantly. Their community contributes to fouling organisms colonizing artificial structures such as oil platforms (Basson et al., 1977).In the oyster beds of the Qatari waters, fouling organisms settle on hard surfaces such as the pearl shells which form suitable areas where the larvae of these animals That can grow and at the same time the oyster obtains its food from the settlers.

The study showed that QS2 has the highest number of fouling taxa (30 spp.) in the pearl oyster beds and station QS6 has the lowest fouling taxa number (10 spp.) among all stations investigated. This might be related to environmental parameters that favour the settelment of fouling larvae.

Satuito et al. (1997) reported two such factors influencing settlement (attachment and metamorphosis) of marine invertebrate larvae which are of great importance in aquaculture and the control of biofouling: (a) influence of age (endogenous factor) on cyprids of the barnacle Balanus amphitrite; and (b) influence of a microbial film (exogenous factor) on pediveligers of the mussel Mytilus galloprovincialis. The settlement response to cypris larvae of $B$. amphitrite was found to be age-dependent, where older cyprids responded more readily to settlement factors, but newly molted ones did not. Nair and Meenakumari (1998) reported that the higher fouling biomass is attributed to the profusion of species, their faster growth and attainment of sexual maturity at an early date in the tropics. Walters and Wethey (1996) predicted that refuge dimension and growth form would influence settlement and short-term postsettlement success of sessile marine invertebrates that live attached to hard substrata in low energy environments. They reported that one must be very cautious when generalizing about refuge quality on heterogeneous surfaces, and to determine if a location is a spatial refuge, it is critical to consider: (I) the dimensions of the larvae, (II) the relative dimensions of the individual and potential refuge location at any point in time from the moment of settlement, and (III) the growth form of the individual which is related to its need for protection from biotic and abiotic sources of mortality.

The Shannon and evenness indices in the studied stations varied from $(D=2.890, E=0.841)$ to $(D=2.084, E=0.605)$. They were relatively high at station QS2 and lower at station QS6 (Tab.2). The relative abundance data showed that fouling at station QS2 was composed of three major groups, Crustacea ( $22.8 \%$, by no.), 
Polychaeta ( $34.8 \%$, by no.) and Mollusca ( $16.5 \%$, by no.), while station QS6 showed higher values for Crustacea ( $41.2 \%$, by no.) and Polychaeta $(47.1 \%$,by no.).In general, 111 biofouling species from the whole studied stations were identified. Crustacea such as barnacles (Balanus amphitrite) and amphipods; Mollusca and Polychacta represented the major fouling constituents. The distribution of these fouling organisms among the whole investigated stations showed that some fouling species have a wider distribution, while others were limited. The reduced number of fouling species and their abundance in some of these stations seem more likely to be due to the shells size in the pearl oyster beds. The general increase in fouling abundance is probably a result of increased food availability and increased substrate surface (shell size/ oyster beds) that would support much higher numbers of fouling organisms to be attached and settled on shells of pearl oyster.

Yan et al. (1998) reported that biofouling communities were primarily composed of tropical and subtropical littoral species such as acorn barnacles, oysters and pearl oysters etc. They also observed that with the increase of distance from shore, the proportion of biomass occupied by bivalve, particularly Ostridae and Pteriidae, increased. At the same time, a substantial reduction of total biomass and a change in species composition also occurred in the seaward direction.

As for open-sea species, Yan et al. (1998) reported that only Lepas anatifera and L. anserifera were found and in small amounts. The maximum accumulation of fouling was for Balamus reticulatus as the most predominant species. Yan et al. (1999) indicated that in the offshore areas east of Hainan Island in the northern South China Sea hydroids, gooseneck barnacles and oysters were the most important fouling species. The maximum fouling accumulations were observed in near surface waters and substantial reduction of biomass and species diversity occurred with increasing depth and distance from shore. In the east coast of India, Rajagopal et al. (1997) recorded a high total of 105 fouling taxa as the major fouling organisms. These were hydroids, barnacles, mussels, anthozoans and ascidians with a considerable faunistic and biomass variations noticed at $4 \mathrm{~m}$ depth. He attrebuted this very high biomass accumulation to the extremely dense settlement of musse!s, especially the green mussel, Perna viridis.

In the Shantou Harbour in China, Li et al. (1996) identified 119 species of fouling organisms, 72 species on test panels, 70 
species on buoys and ship bottom, and 54 species on the wharf and the dominant species were Balanus uliginosus, B. reticulatus, Ostrea cucullata, Perna viridis, Anthopleura pacifica, Obelia dichotoma and Bimeria francina.

Hunter (1986) referring to the Arabian Gulf, correlated the distribution of the organisms to water circulation and nutrition concentration. In the present study, the distribution of the biofouling organisms was found to be among investigated stations affected by several environmental factors. These include salinity and temperature fluctuation, the current regime, water circulation and variable changes in nutrient contents. Other physical and chemical parameters might be considered as limiting factors affecting the distribution pattern of dominant species in the study stations and the whole Arabian Gulf.

It remains to be said that short and long term studies are needed to provide more information regarding the physical parameters that might affect the seasonality, diversity and distribution of fouling organisms on the pearl oyster beds or other hard substrata in the Qatari waters.

\section{ACKNOWLEDGEMENT}

The authors wish to express their thanks to Dr. Mohsin A. AlAnsi and Mr. Mohammed S. Al-Mohanadi for their help in diving and collecting samples. We are also grateful to all scientific staff and crew on board R/V "Mukhtaber Al-Bihar" of the University of Qatar, for their assistance. Last and not least, we are grateful to Professor Ekhlas M. Abdel Bari from Department of Biology, who kindly read the manuscript.

\section{REFERENCES}

Basson, P.W.; Burchard J.E., Hardy.J.T.and Price, A.R.(1977). Bjotopes of The Western Arabian Gulf. "Marine life and Environments of Saudi Arabia".Aramco, in Saudi Arabia.284 pp.

Henrikson, A. A.; Pawlik,J.R.; Clare, A. S.; Fusetani, N. and Jones, M.B. (1998). Seasonal variationin biofouling of gels containing extracts of marine organisms. Biofouling , 12 (1-3): 245-255.

Hunter,J.B.(1986). The physical oceanography of the Arabian Gulf. A review and theoretical interpretation of previous observations. Proceeding of the $1^{\text {st }}$.Arabian Gulf Conference on Environment and Pollution, Kuwait. 
Jones,H.D. (1984). Shell cleaning behaviour of Calliostoma ziæyphinium. J. Moll. Stud.,50:245-247.

Chuanyan Li; Huang, Z., Zheng, C. and Wang, J.(1996). Ecological studies on fouling organisms in Shantou Harbour. J. Oceanogr., 15 (1): 19-24.

Nair,N.U and Meenakumari,B.(1998).Seasonal Changes of the Major Fouling Organisms in Cochin Harbour.Ocean. Res.,20 (1) :43-49.

Raffaelli, D. and Hawkins. S.(1996). "Intertidal Ecology". Chapman \& Hall, London, 356pp.

Rajagopal, S. ; Nair, K. V. K.;Van Der Velde, G. and Jenner, H.A. (1997). Seasonal settlement and succession of fouling communities in Kalpakkam, east coast of India. Neth. J. Aquat. Ecol.,30(4):309 - 325.

Satuito,C.G.; Shimizu, K. and Fusetani, N.(1997). Studies on the factors influencing larval settlement in Balamus amphitrite and Mytilus galloprovincialis. Hydrobiol, $358(1-3): 275-280$.

Valiela,I.(1995). "Marine Ecological Processes". Springer-Verlag, New York, 686p.

Walters, L. J. and Wethey, D.S.(1996).Settlement and early postsettlement survival of sessile marine invertebrates on topographically complex surfaces: The importance of refuge dimensions and adult morphology. Mar. Ecol. Prog. Ser., $137(1-3): 161-171$.

Yan, T.;Yan,W.;Dong, Y.;Wang, H.;Yan, Y.;Liang,G. and Zhu, J. (1998). Investigation of marine fouling in northeastern Beibu Gulf. Trop. Oceanol.,17 (2): 38-44.

Yan,T.;Yan, W.; Dong, Y.;Wang, H.;Yan,Y. and Liang, G.(1999). Marine fouling in offshore areas east of Hainan Island, northern South China Sea. Chin. J.Oceanol. Limnol., 17 (3): 233-239. 
Tabie 1 Numbers of major fouling species collected from oyster beois in Qatari Wiaters.

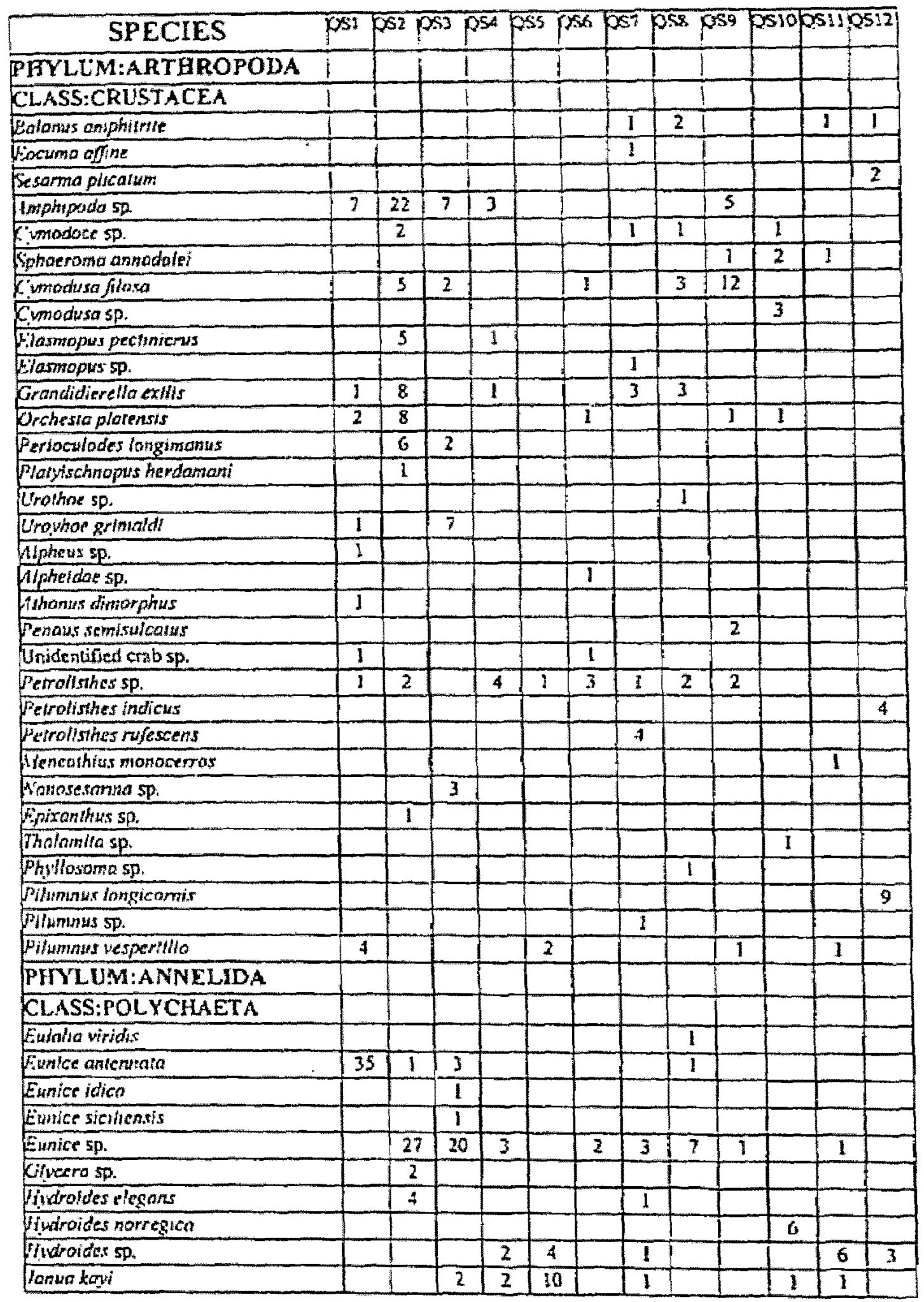


FOULING IN THE PEARL OYSTER BEDS OF THE QATARI 157 WATERS, ARABIAN GUZF

Table 1 (Con)

\begin{tabular}{|c|c|c|c|c|c|c|c|c|c|c|c|c|}
\hline SPECIES & 061 & Cs: & RSi & Cost & $p^{55}$ & pso & Q57 & QSB & QSS & psiog & psin & QSI? \\
\hline Eepidonrus carnitatus & 1 & & & & & & & & & & 1 & \\
\hline Tystier collans & & & & 3 & & & & & 1 & & & \\
\hline Acphthys hombergil & & 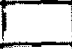 & & & & & & 1 & & 1 & & \\
\hline Ferens sp & 5 & 14 & & & & 1 & 3 & 4 & 4 & & 1 & 1 \\
\hline Polychaels Lara & 3 & 3 & & & & & & & & & & \\
\hline Polichacta sp. & 1 & & & 2 & & & & & 5 & & I & \\
\hline Polutortes melano.us & 2 & & & & & 5 & & & & & & \\
\hline Pomoloceros trigueler. & & & & & & & & & & 4 & 3 & \\
\hline Prionospio pinnolo & & 1 & & & & & & 1 & & 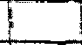 & & \\
\hline Sebella fusca & & & 1 & & 3 & & & & & & & \\
\hline Sylis comsta & & 1 & & & & & & & & & & \\
\hline Syllis prolifera & & 1 & & & & & & & & & & \\
\hline Syllis sp. & 2 & 1 & & & & & 2 & & & 3 & & \\
\hline Gonioda sp. & & 1 & & & & & & & & & & \\
\hline \multicolumn{13}{|l|}{ PEILUM:MOLLUSCA } \\
\hline \multicolumn{13}{|l|}{ CLASS:BIVALVE } \\
\hline Anadara chrenbengi & & & & & & & & & & & 1 & \\
\hline Anomio achoeus & & & & & & & & & & 1 & 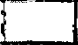 & \\
\hline Borbotia plicolo & & & & 2 & & & & & & & & \\
\hline Brachidonies emarginalus & 5 & 10 & 12 & & & 1 & & 2 & 2 & & & \\
\hline Erachidontes sp. & & 2 & & 2 & & & 1 & 1 & & 11 & 12 & \\
\hline Brachidonies variabilis & & & & & & & & & & 10 & 2 & 2 \\
\hline Choma cspera & & & 2 & 10 & $I$ & & & & & 51 & 10 & 3 \\
\hline Sognoninta sp. & & & & & & & 1 & & & - & & \\
\hline Lishophaze sp. & & & & & & & & & & 7 & & \\
\hline Lfolleus regula & & & & 2 & 5 & & & & & 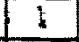 & & 2 \\
\hline Ifadruffundus normolis & & & & & & & & & & 3 & & \\
\hline Sodiolys sp. & & & & & & & & & & & & 17 \\
\hline Ostreo sp. & & & & & & & & & & 4 & 1 & \\
\hline Porviperna nucleus & & & & & & & & & & 1 & & \\
\hline Pinciada radiala & $\$ 6$ & 14 & & 15 & 13 & & 16 & 17 & 14 & 7 & 4 & 9 \\
\hline Plicarila oushrala & & & & & & & & & & 5 & 2 & \\
\hline Tridacto sp. & 1 & & & & & & & & & & & \\
\hline \multicolumn{13}{|l|}{ CLASS:GASTROPODA } \\
\hline Clvperamorus bifasciala & & & 1 & & & & & & 1 & & & \\
\hline Clvpeomaras sp. & & & & & 3 & & & & & & & \\
\hline Dentrodoris SP. & & & & & & & & $I$ & & & & \\
\hline Diodora sp. & 1 & & & & & & & & & & & \\
\hline Doriopsilla miniara & 8 & & 1 & 6 & & 1 & & 1 & & & & \\
\hline Litroring sp. & & & & & 1 & & & & & & & \\
\hline Wonodonto anstrolis & & & & & & & & & 1 & 1 & & \\
\hline Giassarias albescens gemmuliferas & & & & & & & & & & & & 1 \\
\hline Turritclio sp. & & & & & & & & 1 & & & & \\
\hline \multicolumn{13}{|l|}{ CLASS:AMPHINEURA } \\
\hline Sschnothiton sp. & & 3 & 1 & & & & 1 & 2 & & & & \\
\hline \multicolumn{13}{|l|}{ PHYLUM:ECHINODERMATA } \\
\hline \multicolumn{13}{|l|}{ CLASS:STELLEROIDA } \\
\hline Woerophiathrix sp. & & & & & & 1 & 1 & & & & & \\
\hline Ophtothele donae & 8 & 2 & & & & & & & & & & \\
\hline
\end{tabular}




\section{I58 Jassim A. Al-Khayat and Ibrahim A. Al-Maslamani}

Table I (Cont.)

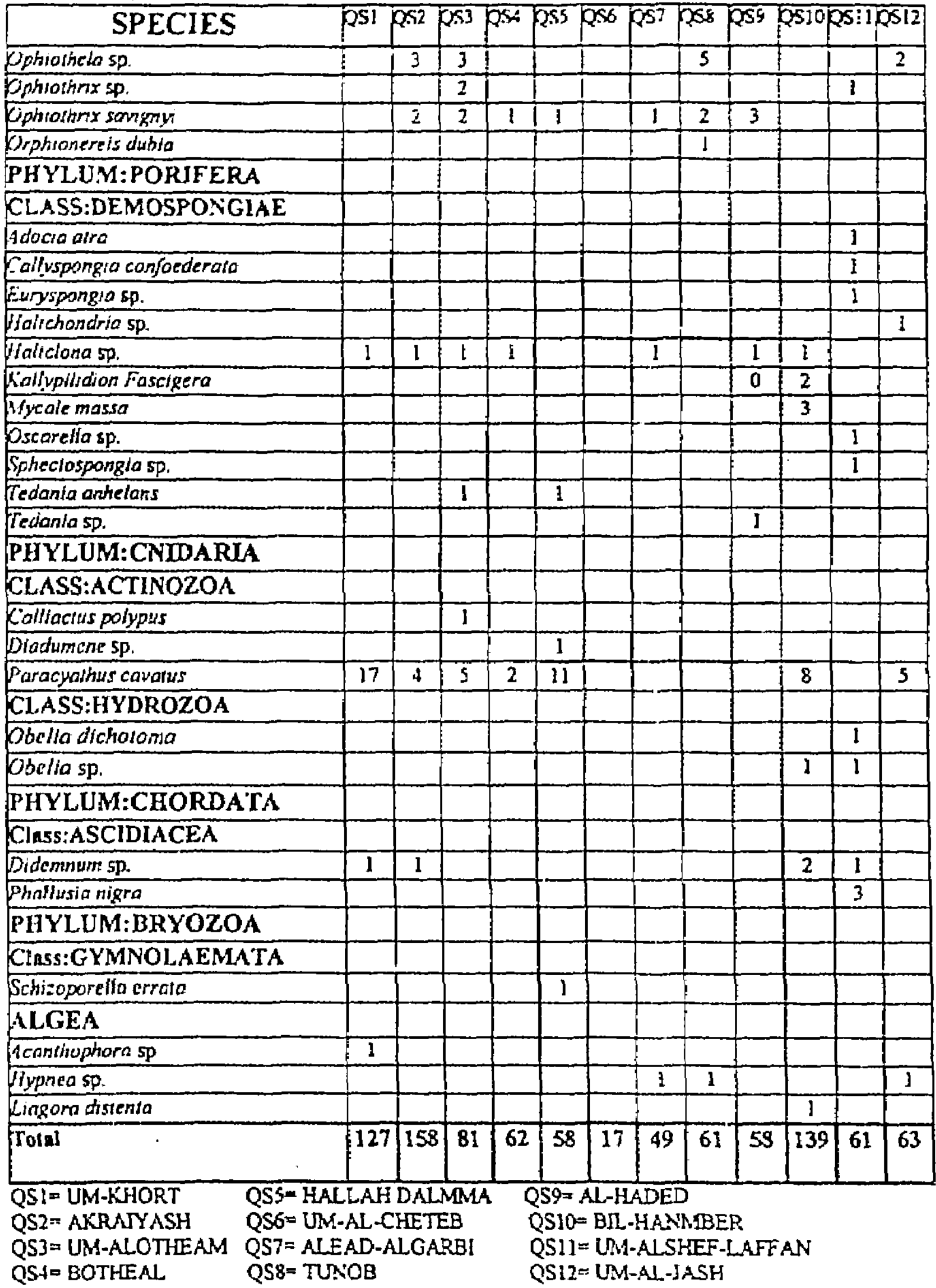


Table 2 : Species diversity indices of biofouling at 12 sampling stations of pearl oyster beds.

\begin{tabular}{|c|c|c|c|}
\hline Station & Species diversity $(\mathrm{H})$ & Evenness (E') & No. of species \\
\hline QS1 & 2.537 & 0.779 & 26 \\
\hline QS2 & 2.890 & 0.841 & 30 \\
\hline QS3 & 2.626 & 0.838 & 23 \\
\hline QS4 & 2.522 & 0.872 & 17 \\
\hline QS5 & 2.262 & 0.835 & 16 \\
\hline QS6 & 2.084 & 0.605 & 10 \\
\hline QS7 & 2.546 & 0.824 & 21 \\
\hline QS8 & 2.676 & 0.842 & 24 \\
\hline QS9 & 2.408 & 0.833 & 18 \\
\hline QS10 & 2.554 & 0.767 & 28 \\
\hline QS11 & 2.824 & 0.857 & 27 \\
\hline QS12 & 2.342 & 0.845 & 15 \\
\hline
\end{tabular}


Tabie 3 : Number of species and percentages (\%) of different fouling groups at the investigated stations.

\begin{tabular}{|c|c|c|c|c|c|c|c|c|c|c|c|c|}
\hline Tin & QSI & os: & 0.5 & Ost & coss & $\theta s$ & 0,8 & 05 & OSs & 0510 & os & $\begin{array}{l}\text { os } \\
12\end{array}$ \\
\hline Crutuces & Eutu & $\begin{array}{c}16 \\
1333\end{array}$ & 12172 & [23.5) & (12.3) & $\begin{array}{c}5 \\
1300\end{array}$ & (x) 13 & $r^{7} .13$ & $\left.{ }^{7} 1^{2} .5\right)$ & $\begin{array}{c}5 \\
61703\end{array}$ & $(1<1)$ & 2031 \\
\hline Moturese & 59.21 & (13) & $(2)^{3} 7$ & 294 & $(375)$ & $20^{2} 01$ & $(143)$ & $(29.7)$ & 22.21 & 19 & $25^{7} 01$ & a 53 \\
\hline Palycusete & $(260)$ & $\begin{array}{c}10 \\
(533)\end{array}$ & $(26)$ & $\Omega^{5}$ & (iing & $\begin{array}{c}3 \\
030.09\end{array}$ & $(2 \times 6)$ & (25.0) & (2) & $(103)$ & (22) & [13.J) \\
\hline Dewerespostin & (3.9) & (13) & $\begin{array}{c}2 \\
(27)\end{array}$ & 1 & (c) & . & (16) & 2 & (11.1) & $(10)$ & (I2.5) & $\begin{array}{c}1 \\
(6.7)\end{array}$ \\
\hline Siellerald & (j.9) & $(10.0)$ & (1)० & 19 & $i x$ & - & 25 & $\because$ & 1 & 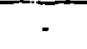 & B. & $(6.7)$ \\
\hline Actimaxue & $(3)$ & [3] & $(2)$ & (9.3) & $2^{2}$ & - & - & 3 & 5 & $\begin{array}{c}1 \\
3,6\rangle\end{array}$ &. & 16.7 \\
\hline Ilydraent & $\cdot$ & $\cdot$ & - & 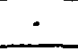 & - & - & $\cdot$ & - & 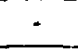 & 0.6 & $0^{2}+1$ & - \\
\hline Axciviares & 13 & (1) & - & - & $=$ & - & - & • & - & $\begin{array}{c}1 \\
(36)\end{array}$ & ${ }^{2}$ & = \\
\hline Itrotan & $\cdot$ & $\cdot$ & - & - & 6 & - & - & $\dot{\cdot}$ & - & - & $=$ & - \\
\hline Alest & 0.91 & $\cdot$ & - & 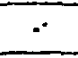 & - & - & $(46)$ & 14 & - & $\begin{array}{c}1 \\
(3.6)\end{array}$ & - & $(6)$ \\
\hline $\begin{array}{l}\text { Tolal to of } \\
\text { eprelict }\end{array}$ & 26. & 30 & 21 & 17 & yo & 10 & 21 & 24 & 18 & 28 & 27 & 15 \\
\hline Dver oll $\%$ & 24 & 21.8 & 20.7 & 15.3 & 14.4 & 9.0 & 11.9 & 21.6 & 162 & 252 & 243 & is.s \\
\hline
\end{tabular}


FOULING IN THE PEARL OYSTER BEDS OF

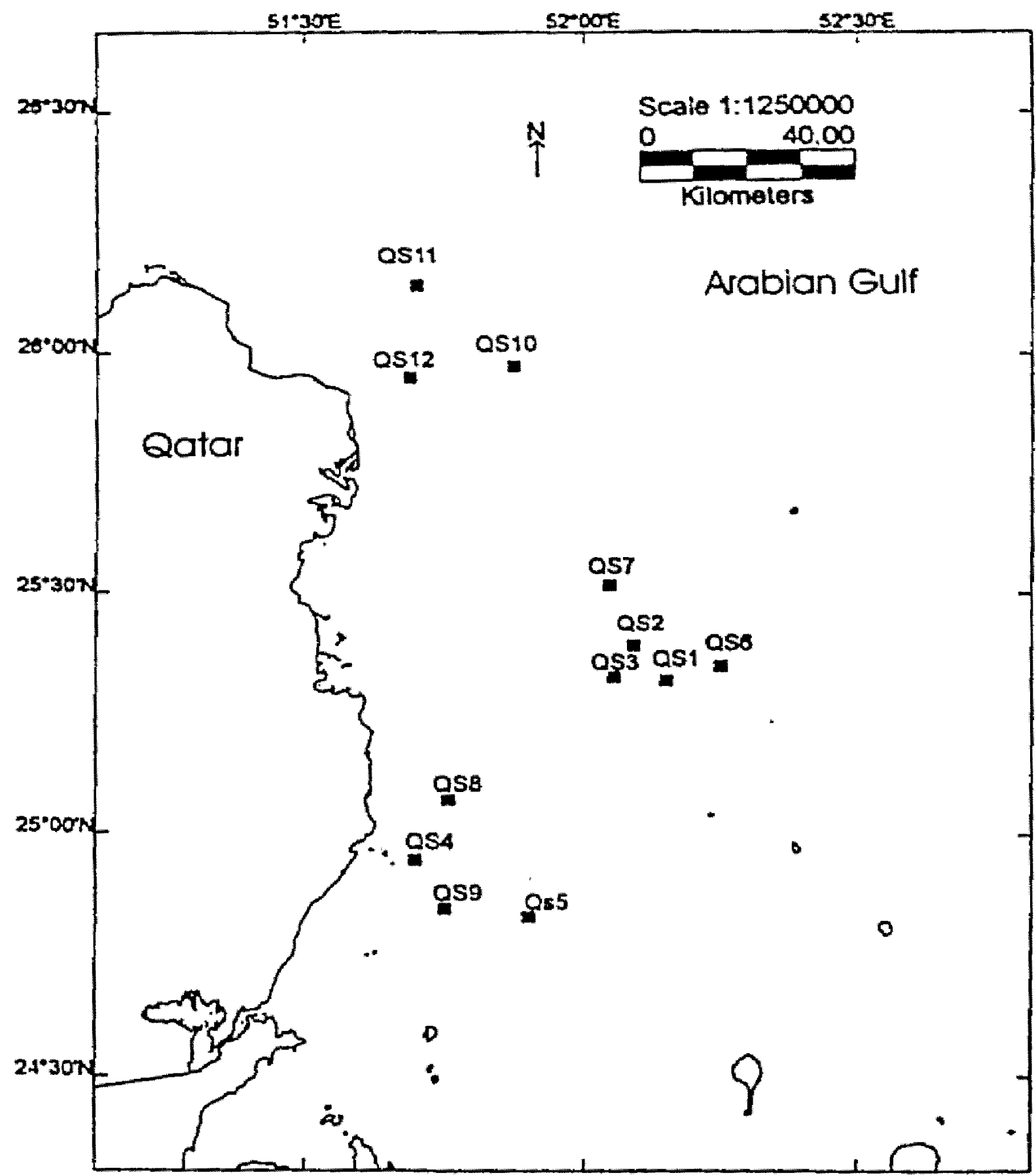

Fig. (I) Sampling stations 


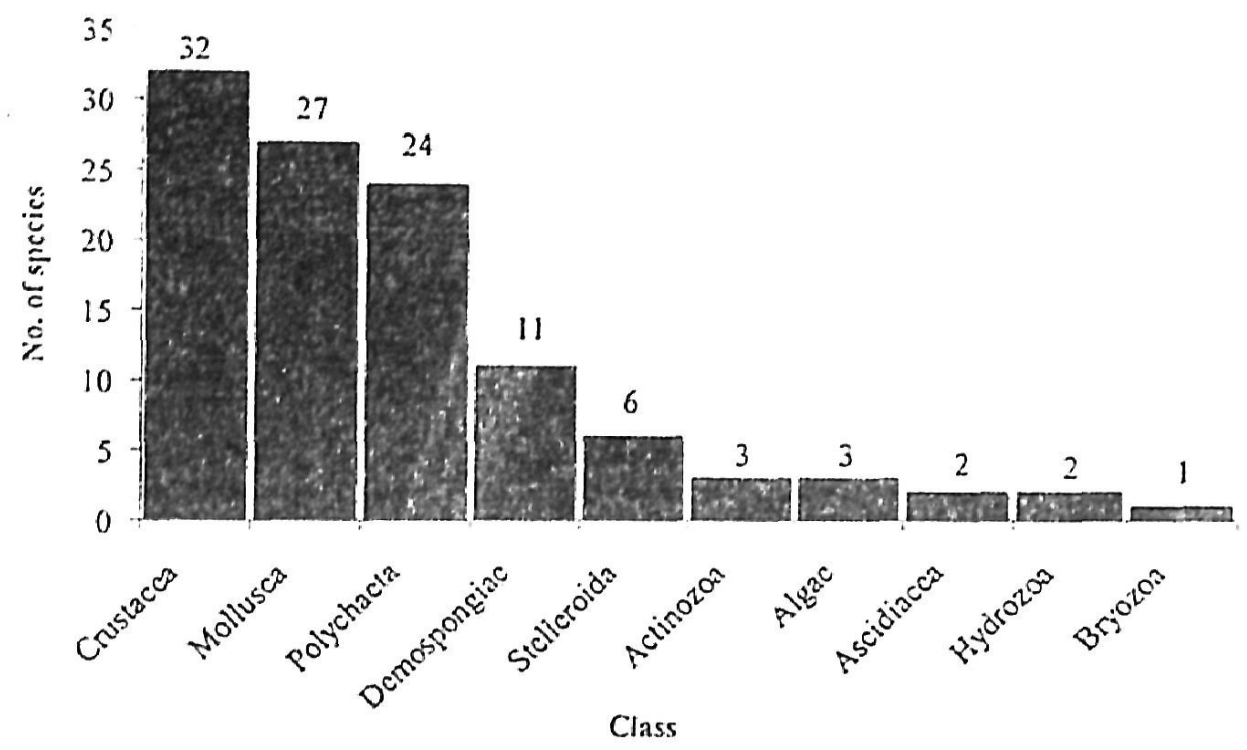

Figure 2 : Numbers of major fouling organisms in the oyster beds of Qatari waters. 